\title{
Moisture Sorption Isotherms of Yogurt Powder Containing Candied Chestnut Puree
}

\author{
Aslı Zungur Bastıoğlu ${ }^{1,2}$, Safiye Nur Dirim ${ }^{1 *}$, Figen Kaymak Ertekin ${ }^{1}$ \\ ${ }^{1}$ Department of Food Engineering, Faculty of Engineering, Ege University, 35100 Bornova/Izmir, Turkey \\ ${ }^{2}$ Department of Food Engineering, Faculty of Engineering, Adnan Menderes University, 09100 Aydin, Turkey \\ A R T I C L E I N F O \\ Article history: \\ Received 08 February 2016 \\ Accepted 13 May 2016 \\ Available online, ISSN: 2148-127X \\ Keywords: \\ Yogurt \\ Powder \\ Freeze drying \begin{abstract}
A B S T R A C T
Yogurt powder was produced by freeze drying and with added candied chestnut puree at ratios of 5,10 , and $20 \%$ by weight. Moisture sorption isotherms of yogurt powder samples, plain (YP), and containing 5, 10, 20\% candied chestnut puree (CCP) were determined at $25^{\circ} \mathrm{C}$ using the standard, static-gravimetric method. The experimental adsorption data of yogurt powders at $25^{\circ} \mathrm{C}$ were fitted to 14 sorption equations which are most widely used to fit experimental sorption data of various food materials. The parameters of the sorption models were estimated from the experimental results by using the nonlinear regression analysis. The GAB model gave the closet fit to the sorption data of freeze dried yogurt powders with candied chestnut puree at $25^{\circ} \mathrm{C}$. BET, Ferro Fanton, Henderson, Halsey, Oswin and Modified Oswin models are also acceptable for describing the adsorption isotherms for freeze dried yogurt with candied chestnut puree at $25^{\circ} \mathrm{C}$.
\end{abstract}

Candied chestnut

Sorption isotherm

${ }^{*}$ Corresponding Author:

E-mail: nur.dirim@ege.edu.tr

\section{Introduction}

With the increasing demand of healthy food products, studies in food science and technology are directed to the development of novel foods either new in composition or in the method of preparation. In the development of these novel foods the priority is usually given for the commonly preferred and consumed foods and the foods that are very important in health benefits. In Turkey, yogurt is among the most consumed foods; however, its consumption is mainly in plain form together with meals. For this reason improvement of yogurt with new additives may also increase its consumption among young people.

Yogurt is a food produced by bacterial fermentation of milk. The high nutritional value and health effect of yogurt make it a highly popular and worldwide consumed fermented food product. The shelf life of yogurt is one day when stored at ambient condition $\left(25-30^{\circ} \mathrm{C}\right)$ and around 5 days at $7^{\circ} \mathrm{C}$ (Kumar and Mishra 2004) and its freshness is not retained for more than 1 week under refrigerated conditions (Kamruzzaman et al., 2002). Improvements in the shelf life of yogurt can be brought about by dehydrating and converting it into a shelf-stable powder. Yogurt can be dried by freeze, spray, microwave or convective drying methods. Dried yogurt in powder form have many applications such as filling in confectionery, ingredients for savory goods, biscuits, cakes, crackers and crisp breads in bakery and also used as pastes in soups, sauces, dips, ready meals, baby foods etc. It can also be consumed directly after reconstitution (Koç et al., 2010). In addition to these, yogurt powder can be used as a functional food that can be mixed with dried fruit particles and nutritional ingredient to formulate a novel product and improve the reconstitution properties of the yogurt.

Addition of chestnut to yogurt may also be a good alternative to fruity yogurt which is very common in the food market. By this way yogurt will be enriched and its flavor will be improved. Chestnut is an important product in Mediterranean countries. Although changing on varieties and seasonal effects, on the average, chestnuts contain $50 \%$ moisture, $42 \%$ carbohydrates $(28 \%$ starch and $14 \%$ sugars, mainly sucrose and in less proportion glucose and fructose), $2.5 \%$ proteins, $2 \%$ fats and the remaining minerals (Moreira et al., 2008; Chenlo et al., 2006). Due to its high moisture content chestnut is easily perishable after the harvest. The methods of preservation of the chestnut can be by drying, keeping in refrigerated storage rooms, in modified atmosphere $\left(10 \% \mathrm{CO}_{2}\right)$, and freezing. Chestnuts can also be canned, pureed, or preserved in sugar or syrup. Production and consumption of candied chestnuts is very common in Turkey. This product protects the nutritional value of fresh chestnuts and adds energy value due to the addition of sugar. 
Food powders have an increasing importance in food processing due to their ease of storage and transportation, and their suitability for use in innovative formulations. Processing methods, like drying, homogenization, crystallization, powder production, and gelatinization change the microscopic structure of the food material (Jaya, 2009). The quality of a powdered food product is affected by the processing conditions, where the final quality is determined by its moisture content, water activity, color and the amount and quality of basic nutrients preserved. Most of the cases, the effect is based on moisture sorption isotherms and they are important in preservation, storage, packaging etc. (Tsami et al., 1990; Chirife and Buera, 1994; Vilades et al., 1995)

Food materials have specific equilibrium moisture content at a particular relative humidity or water activity. Moisture sorption isotherm represents the relationship between the equilibrium moisture content and relative humidity or water activity at a particular temperature (Kaymak-Ertekin, 2004; Varghese et al., 2009; Kumar and Mishra, 2006). Moisture sorption isotherm is unique for each food material and they are useful in understanding the behavior of food during its handling, drying, processing and storage systems (Chirife and Buera 1994; Vilades et al., 1995). The physical, chemical and microbiological stability of food depends on the water content and its interaction with the food component (Silva et al., 2014). For this reason, the data obtained from sorption isotherms help evaluate the storage stability and are also used in the process design and control (Paakkonen and Roos, 1990; Mrad et al., 2012). The data is also used in formulation of new products, selection of packaging materials and storage conditions, as well as in the drying processes (Demarchi et al., 2013). The shapes of the adsorption curves depend on the composition of the powdered product (Arslan and Toğrul, 2005). In addition the sorption isotherms can be used to determine the optimum moisture content of the dried product (Rockland and Nishi, 1980; Slade and Levine, 1991). For the above mentioned reasons, it is important to know the sorption characteristics of dried food materials. Although there are many studies about moisture sorption of food materials, a few of them were reported about the moisture sorption isotherms of yogurt powder (Kim and Bhowmik, 1994; Kumar and Mishra, 2006; Stencl, 2004; Varghese et al., 2009; Koç et al., 2010). Since the sorption behavior and the reconstitution properties of yogurt powder are affected by the drying method, particle size, and raw material properties, determination of the adsorption isotherms of yogurt powder is required for each yogurt product (Koç et al., 2010) with different compositions or method of preparation.

The water sorption in foods is a very complex phenomenon, consisting of several different mechanisms that depend on the material structure and composition. As a consequence, hundreds of models trying to represent the water sorption behavior in food matrices have been proposed. These models are generally classified into three categories: empirical, semi-empirical, and theoretical. As empirical two-parameter models Oswin, Smith and
Henderson equations can be cited among many others. As a semi-empirical example, the Peleg model is given which has four parameters. And finally, derived from the Langmuir isotherm, two theoretical expressions can be cited: the BET and GAB equations, which are considered as the most used models to describe water sorption in food materials. The main advantage of theoretical models over the empirical and semi-empirical ones is the fact that their parameters have physical meaning. As a consequence, the inclusion of temperature dependency into the equation is possible, improving its fitting capability and most importantly, the parameters can provide essential information about the water state in the food. As an example, BET and GAB equations include the monolayer capacity or monolayer moisture content, $\mathbf{M}_{0}$. This parameter constitutes very important information since it is directly related to the shelf life and stability of foods (Staudt et al., 2013). In a previous study, freeze drying of yogurt with chestnut puree was satisfactorily performed by testing the physical and powder properties of yogurt powder together by survival of lactic acid bacteria (Ergun et al., 2013). Freeze drying is considered as the reference process for manufacturing high quality dehydrated products. Compared to classical dehydration techniques, the main advantages of freeze drying process are; the preservation of initial raw material properties such as shape, appearance, taste, color, flavor, texture, biological activity etc. and the high rehydration capacity of the freeze dried product (Mosquera et al., 2012). However, freeze drying is the most expensive drying process and for this reason any further treatment in freeze dried products is not feasible. Therefore, it was assumed that the final product should be suitable for storing at room temperature and the adsorption experiments were performed at $25^{\circ} \mathrm{C}$ accepted as room temperature. The objectives of this study were to establish adsorption isotherms of freeze dried yogurt powder as plain and powder containing 5, 10 and 20\% candied chestnut pure, and to determine the most appropriate model corresponding to the experimental data.

\section{Materials and Methods}

\section{Materials}

White, plain yogurt (14.2\% (wet basis) total solids and $1.5 \%$ fat) was purchased from a local producer (Pinar Dairy Products Inc., Turkey) and kept at $4{ }^{\circ} \mathrm{C}$ until used on the day of purchase. Candied chestnut puree containing $46.8 \%$ total sugar, $0.3 \%$ fat, $24.8 \%$ starch, and $0.9 \%$ protein was purchased from a local supermarket (Kardelen A.Ş., Turkey) and kept at $4{ }^{\circ} \mathrm{C}$ in a closed container.

\section{Preparation of Yogurt Mix}

Yogurts both plain and mixed with candied chestnut puree at $5 \%, 10 \%$, and $20 \%$ by weight were prepared by mixing the ingredients and poured on metal petri plates. Sample thickness was kept at a constant thickness of 3 $\mathrm{mm}$ by measuring with a digital caliper (Ergun et. al., 2013). 
Freezing and Freeze Drying

The samples were frozen in an air-blast freezer (Frigoscandia, Helsinborg, Sweden) at $-18^{\circ} \mathrm{C}$ for 2 hours, and freeze dried for 8 hours in laboratory scale equipment (Armfield Model-FT33 Vacuum Freeze Drier, England) at $13.3 \mathrm{~Pa}$ absolute pressure with a condenser temperature of $-45^{\circ} \mathrm{C}$. Samples were dried to constant weight. All freeze drying experiments were replicated as twice (Ergun et. al. 2013).

\section{Determination of Sorption Characteristics}

The adsorption isotherms of freeze dried plain yogurt powder and freeze dried yogurt powder containing 5, 10 and $20 \%$ candied chestnut puree were determined with the standard static-gravimetric method (Spiess and Wolf 1983; Labuza, 1984). Ten saturated salt solutions were selected to give relative humidity in the range of 0.11 0.87 at $25^{\circ} \mathrm{C}$. Relative humidities of salt solutions at $25^{\circ} \mathrm{C}$ were taken from data reported by Greenspan (1977) (Table 1). A perforated and raised platform was put in each glass jar to support glass weighing dishes. The level of saturated salt solutions in each glass jar was kept below the perforated platform in order to avoid contact of the salt solution and the weighing dishes. A flask containing toluene was placed into the glass jars which have relative humidity higher than $50 \%$ in order to prevent mold formation (Labuza, 1984; Wolf et al., 1985; Rapusas et al., 1993). Three replications of the same experiment were carried out. The glass sorption jars were placed in a temperature-controlled cabinet at $25^{\circ} \mathrm{C}$. The samples were weighed periodically (7-day intervals) with an electronic balance having an accuracy of 1 (mg) until they attained equilibrium. Equilibrium was reached when the difference in the sample weight between two successive measurements was less than the balance accuracy as $0.001 \mathrm{~g}$. The equilibrium moisture content of the samples was determined by drying in a vacuum oven at $70^{\circ} \mathrm{C}$ for 4h. To establish moisture sorption isotherms, the equilibrium moisture contents were plotted against water activity.

\section{Modelling Equations}

A detailed search of the literature showed that moisture sorption isotherms of foods can be described by more than one sorption model (Kaymak-Ertekin and Sultanoglu 2001; Kaymak-Ertekin and Gedik, 2004). The criteria used to select the most appropriate sorption model were the degree of fit to the experimental data and the simplicity of the model. The experimental adsorption data of yogurt powders at $25^{\circ} \mathrm{C}$ were fitted to 14 sorption equations shown in Table 2 . All equations in Table 2 were chosen because they are most widely used to fit experimental sorption data of various food materials. The parameters of the sorption models were estimated from the experimental results by using the nonlinear regression analysis (SPSS 15.0 for Windows) which minimizes the residual sum of the squares. Best fitting equations were evaluated with the mean relative percentage deviation $(\mathrm{P})$ value (Eq. 15) and percentage root mean squares error (RMSE) value (Eq. 16). P value is defined as:

$$
\begin{aligned}
& \% \mathrm{P}=\frac{100}{\mathrm{~N}} \sum_{\mathrm{i}=1}^{\mathrm{N}} \frac{\left|\mathrm{M}_{\exp }-\mathrm{M}_{\text {cal }}\right|}{\mathrm{M}_{\exp }} \\
& \text { and RMSE value defined as } \\
& \% \mathrm{RMSE}=\frac{1}{\mathrm{~N}} \sum_{\mathrm{i}=1}^{\mathrm{N}}\left(\frac{\left|\mathrm{M}_{\exp }-\mathrm{M}_{\text {cal }}\right|}{\mathrm{M}_{\mathrm{exp}}}\right)^{2} \times 100
\end{aligned}
$$

Where $\mathbf{M}_{\exp }$ and $\mathbf{M}_{\text {cal }}$ are experimental and predicted moisture content values, respectively, and $\mathrm{N}$ is the number of experimental data. A model was considered to be acceptable if the $\mathrm{P}$ values and RMSE values were below $10 \%$ and $\mathrm{R}^{2}$ values were higher than 0.9 (Lomauro et al., 1985; Kaymak-Ertekin and Sultanoğlu, 2001; Kaymak-Ertekin and Gedik, 2004; Wang and Brennan 1991).

\section{Results}

The change of equilibrium moisture content with respect to $a_{w}$ is given in Table 3 for yogurt powder samples, plain (YP), and containing 5, 10, 20\% candied chestnut puree $(\mathrm{CCP})$ at $25^{\circ} \mathrm{C}$, where the equilibrium moisture content at each $\mathrm{a}_{\mathrm{w}}$ represents the mean value of three replications. As expected, results showed that equilibrium moisture increases with the increase in water activity. At higher $a_{w}$ values, equilibrium moisture increased, showing type II behavior according to the Brunauner, Emmett and Teller, (BET) classification. Most biological materials follow a sigmoid curve representing the type II isotherm of BET classification (Madamba et al., 1994). This finding is consistent with the results of Kumar and Mishra (2002), Varghese et al. (2009), Koç et al. (2010).

Table 1 Amount of salt and water to prepare saturated salt solution and water activity exhibited by saturated salt solutions at $25^{\circ} \mathrm{C}$

\begin{tabular}{c|lcccc}
\hline Sample Number & & Salt & Salt $(\mathrm{g})$ & Water $(\mathrm{g})$ & $\mathrm{a}_{\mathrm{w}}$ \\
\hline 1 & $\mathrm{LiCl}$ & 150 & 85 & 0.113 \\
2 & $\mathrm{CH}_{3} \mathrm{COOK}$ & 200 & 65 & 0.226 \\
3 & $\mathrm{MgCl}_{2}$ & 200 & 25 & 0.327 \\
4 & $\mathrm{~K}_{2} \mathrm{CO}_{3}$ & 200 & 90 & 0.432 \\
5 & $\mathrm{Mg}\left(\mathrm{NO}_{3}\right)_{2}$ & 200 & 30 & 0.529 \\
6 & $\mathrm{NaBr}$ & 200 & 80 & 0.576 \\
7 & $\mathrm{SrCl}_{2}$ & 200 & 50 & 0.709 \\
8 & $\mathrm{NaCl}_{9}$ & $\mathrm{NH}_{3} \mathrm{SO}_{4}$ & 200 & 60 & 0.753 \\
10 & $\mathrm{KCl}$ & 200 & 70 & 0.810 \\
\hline
\end{tabular}


Table 2 Sorption models described sorption isotherms of food materials

\begin{tabular}{|c|c|c|}
\hline Model Name & Equation & \\
\hline GAB(Guggenheim-Andersen-de Boer) (Van den Berg, 1985) & $\mathrm{M}=\left(\mathrm{M} 0 * \mathrm{C}^{*} \mathrm{~K} * \mathrm{a}_{\mathrm{w}}\right) /\left(\left(1-\left(\mathrm{K}^{*} \mathrm{a}_{\mathrm{w}}\right)\right) *\left(1-\left(\mathrm{K}^{*} \mathrm{a}_{\mathrm{w}}\right)+\left(\mathrm{C} * \mathrm{~K}^{*} \mathrm{a}_{\mathrm{w}}\right)\right)\right)$ & (1) \\
\hline BET (Brunauer, Emmett and Teller, 1938) & $\mathrm{M}=\left(\mathrm{M} 0 * \mathrm{C} * \mathrm{a}_{\mathrm{w}}\right) /\left(\left(1-\mathrm{a}_{\mathrm{w}}\right)+(\mathrm{C}-1) *\left(1 \mathrm{a}_{\mathrm{w}}\right) * \mathrm{a}_{\mathrm{w}}\right)$ & (2) \\
\hline Chung - Pfost (CHUNG and PFOST, 1967) & $\mathrm{a}_{\mathrm{w}}=\exp [-\mathrm{k} / \mathrm{RT} \exp (-\mathrm{cM})]$ & (3) \\
\hline Halsey (HALSEY, 1948) & $\mathrm{a}_{\mathrm{w}}=\exp (-\mathrm{k} / \mathrm{Mn})$ & (4) \\
\hline Henderson (HENDERSON, 1952 ) & $1-\mathrm{a}_{\mathrm{w}}=\exp (-\mathrm{k} \mathrm{T} M \mathrm{n})$ & $(5)$ \\
\hline Iglesias- Chirife (IGLESIAS and CHIRIFE, 1978) & $\ln \left[\mathrm{M}+\left(\mathrm{M}^{2}+\mathrm{M} 0.5\right) 1 / 2\right]=\mathrm{k} \mathrm{a}_{\mathrm{w}}+\mathrm{c}$ & (6) \\
\hline Oswin (OSWIN, 1946) & $\mathrm{M}=\mathrm{k}\left(\mathrm{a}_{\mathrm{w}} / 1-\mathrm{a}_{\mathrm{w}}\right) \mathrm{n}$ & (7) \\
\hline Modified Chung-Pfost (CHUNG and PFOST, 1967) & $\mathrm{M}=(-1 / \mathrm{n}) \ln \{[-(\mathrm{T}+\mathrm{c}) \ell \mathrm{n}(\mathrm{aw}) / \mathrm{k}]\}$ & $(8)$ \\
\hline Modified Halsey (HALSEY, 1948) & $a_{w}=\exp [-\exp (k T+c) M-n]$ & (9) \\
\hline Modified Henderson (HENDERSON, 1952) & $\mathrm{M}=\left\{\ln \left(1-\mathrm{a}_{\mathrm{w}}\right) /[-\mathrm{k}(\mathrm{T}+\mathrm{c})]\right\} 1 / \mathrm{n}$ & $(10)$ \\
\hline Ferro Fontan (FERRO FONTAN et al., 1982) & $a_{\mathrm{w}}=\mathrm{a} /\left(\operatorname{Exp}\left(\mathrm{b}^{*} \mathrm{M}^{* *}-\mathrm{r}\right)\right)$ & (11) \\
\hline Peleg (PELEG, 1988) & $\mathrm{M}=\left(\mathrm{k} * \mathrm{a}_{\mathrm{w}} * * \mathrm{n}\right)+\left(\mathrm{c} * \mathrm{a}_{\mathrm{w}} * * \mathrm{~b}\right)$ & $(12)$ \\
\hline Smith (ROCKLAND and STEWART, 1981) & $\mathrm{M}=(\mathrm{a}+\mathrm{b} * \mathrm{~T})-\left(\mathrm{c}+\mathrm{d}^{* T}\right) * \mathrm{LN}\left(1-\mathrm{a}_{\mathrm{w}}\right)$ & (13) \\
\hline Modified Oswin (OSWIN, 1946) & $\mathrm{M}=(\mathrm{a}+\mathrm{b} * \mathrm{~T}) *\left(\mathrm{a}_{\mathrm{w}} /\left(1-\mathrm{a}_{\mathrm{w}}\right)\right) *{ }^{2} \mathrm{c}$ & $(14)$ \\
\hline
\end{tabular}

${ }^{*} \mathrm{k}, \mathrm{c}, \mathrm{b}$ and $\mathrm{n}$, constants of sorption models; $\mathrm{a}_{\mathrm{w}}$, water activity ; M , equilibrium moisture content (dry basis) ; M0,5, moisture content when $\mathrm{a}_{\mathrm{w}}=0,5$ (dry basis); R, gas constant (kJ/mol.K) and T, absolute temperature (K)

Table 3 Equilibrium moisture content $(\mathrm{kg} / \mathrm{kg}$ dry solids) of freeze dried yogurt powder samples

\begin{tabular}{c|cccc}
\hline $\mathrm{a}_{\mathrm{w}}$ & YP & $5 \% \mathrm{CCP}$ & $10 \% \mathrm{CCP}$ & $20 \% \mathrm{CCP}$ \\
\hline 0.113 & $0.023 \pm 0.003$ & $0.010 \pm 0.005$ & $0.009 \pm 0.001$ & $0.007 \pm 0.003$ \\
0.226 & $0.040 \pm 0.005$ & $0.023 \pm 0.015$ & $0.024 \pm 0.005$ & $0.011 \pm 0.000$ \\
0.327 & $0.062 \pm 0.015$ & $0.035 \pm 0.003$ & $0.030 \pm 0.004$ & $0.022 \pm 0.003$ \\
0.432 & $0.089 \pm 0.002$ & $0.059 \pm 0.024$ & $0.052 \pm 0.009$ & $0.045 \pm 0.012$ \\
0.529 & $0.140 \pm 0.003$ & $0.084 \pm 0.003$ & $0.075 \pm 0.005$ & $0.052 \pm 0.001$ \\
0.576 & $0.181 \pm 0.001$ & $0.100 \pm 0.018$ & $0.086 \pm 0.002$ & $0.073 \pm 0.003$ \\
0.709 & $0.243 \pm 0.019$ & $0.172 \pm 0.006$ & $0.157 \pm 0.002$ & $0.139 \pm 0.009$ \\
0.753 & $0.277 \pm 0.008$ & $0.205 \pm 0.007$ & $0.191 \pm 0.004$ & $0.173 \pm 0.000$ \\
0.810 & $0.346 \pm 0.002$ & $0.279 \pm 0.012$ & $0.270 \pm 0.007$ & $0.242 \pm 0.009$ \\
0.843 & $0.425 \pm 0.005$ & $0.349 \pm 0.005$ & $0.330 \pm 0.005$ & $0.316 \pm 0.008$ \\
\hline
\end{tabular}

(YP: Freeze dried plain yogurt powder; 5\%CCP:Freeze dried yogurt powder contain 5\% candied chestnut puree; 10\%CCP:Freeze dried yogurt powder contain $10 \%$ candied chestnut puree; $20 \% \mathrm{CCP}$ :Freeze dried yogurt powder contain $20 \%$ candied chestnut puree)

As seen in the Figure 1, freeze dried plain yogurt powder has higher equilibrium moisture content (EMC) than freeze dried yogurt powders containing candied chestnut puree. Equilibrium moisture content of yogurt powders decreased with increasing of candied chestnut puree ratio. Although equilibrium moisture contents of yogurt powders containing candied chestnut puree are low, when water activity rises above 0.7 , an increase in the equilibrium moisture content was observed.

In literature, "break point" was reported in the isotherms of dairy powders due to lactose crystallization (Berlin et al., 1968; Iglesias and Chirife, 1982; Foster et al., 2004). Such a break point was not observed in our study due to the low level of lactose in the fermented products by the action of culture organisms. Also Stencl (2004), Varghese et al (2009) and Koç et al. (2010) did not observe the break point in their experiment about the determination the moisture sorption isotherms of yogurt powder.

The sorption models presented in Table 2 were chosen to fit the experimental sorption data because they are the most widely used ones for several foods. Model parameters were estimated by taking the EMC to be the dependent variable. To calculate the parameters of the equation, a nonlinear regression analysis minimizing the residual sum of squares was applied within the range of 0-0.9 water activity, except for the BET equation which is valid only for water activity below 0.5 . The results of nonlinear regression analysis of fitting the sorption equations to the experimental data, the mean relative percentage deviation (P), RMSE, and correlation coefficient $\left(R^{2}\right)$ values are presented in Table 4.

Experimental data were fitted to $\mathrm{GAB}$ equation and $\mathrm{P}$ values were calculated as 6.6, 2.3, 3.6, 9\% and RMSE values were found to be $2.6,0.7,1.0,1.8 \%$ for plain yogurt powder and yogurt powders containing 5, 10 and $20 \%$ candied chestnut puree, respectively. The GAB equation, the most widely used, seems to be most suitable to describe the moisture sorption isotherms of freeze dried yogurt powder for a wide range of water activity $(0.11-$ 0.87) with the least values for $\mathrm{P} \%$ and RMSE on equilibrium moisture content (Table 4). Kumar and Mishra (2002), Varghese et al. (2009), Koç et al. (2010) reported that the $\mathrm{GAB}$ model gave the best prediction of the sorption data of yogurt powders. Also GAB model was found best fitted model for chestnut sorption (Vazquez et al., 2001). The experimental adsorption data and the predicted values obtained from $G A B$ model at 
$25^{\circ} \mathrm{C}$ are also shown in Figure 1. The monolayer moisture content $\left(\mathrm{M}_{0}\right)$ helps to define physical and chemical stability of foods because it has a direct influence on enzyme activity, non-enzymatic browning, flavor preservation, and product structure. The GAB monolayer moisture contents for freeze dried yogurt powder were in the range of $0.063-0.114 \mathrm{~kg} / \mathrm{kg}$ dry solid (Table 3 ). $\mathrm{M}_{0}$ values decreased with increasing of candied chestnut puree ratio. Similar results have been reported in the study of Kumar and Mishra (2002) about determining the sorption isotherms of plain yogurt, mango-soy-fortified yogurt powder. According to their study, the monolayer moisture content of plain yogurt powder is higher than the others. Higher $\mathrm{M}_{0}$ of may be due to considerably high sorption capacity through the swelling of colloidal material increasing more polar sites (Mishra et al., 1996). The GAB monolayer moisture content for spray dried yogurt powder was given as $0.136 \mathrm{~kg} / \mathrm{kg}$ dry solid and the $\mathrm{M}_{0}$ value obtained by the GAB equation was higher than that obtained by the BET model (Koç et al., 2010). In our study a similar trend was also observed for plain yogurt and $\mathbf{M}_{0}$ values for both models are lower compared to spray dried yogurt. Kumar and Mishra (2006) reported that $\mathrm{M}_{0}$ values estimated from the GAB model were between 3.02-1.79\% (dry basis) for adsorption of convectively dried yogurt powder which are higher than our findings. The constants $\mathrm{K}$ and $\mathrm{C}$ for freeze-dried yogurt powders in the $\mathrm{GAB}$ equation varied in the range of 0.908-0.999 and 0.702-1.742 respectively. For spray dried yogurt powder $\mathrm{K}$ values of the $\mathrm{GAB}$ equation were expressed as between 0.85 and 0.91 (Koç et al., 2010). The value of $\mathrm{K}$ provides a measure of the interactions between the molecules in multilayer with the adsorbent and tends to fall between energy value of the molecules in the monolayer and that of liquid water.

The BET equation was fitted to four water activity values only because this model is valid for $\mathrm{a}_{\mathrm{w}}$ below 0.5 .
Since this equation is reported to be one of the most suitable models to describe the sorption behavior of food contains high amount of carbohydrates (Sopade and Ajisegeri, 1994; Al-Muhtaseb et al., 2002), it seems reasonable that it is suitable to describe the freeze dried yogurt powder with candied chestnut puree. $\mathrm{M}_{0}$ value obtained from GAB equation is higher than the value obtained from BET equation for plain yogurt. The BET monolayer moisture contents for yogurt powder were $0.070-0.092 \mathrm{~kg} / \mathrm{kg}$ dry solid for spray dried yogurt (Koç et al., 2010); in their study, it was also reported that, the $\mathrm{M}_{0}$ value obtained by the GAB equation was higher than that obtained by the BET model. Basu et al. (2006) and Koç et al. (2010) also reported that the $\mathrm{M}_{0}$ value given by the BET isotherms is always lower than the monolayer value derived from GAB and, reversibly, the BET value of energy constant is always higher than the GAB value. However, in our study, this behavior is not observed for the powders containing chestnut puree.

In addition to GAB and BET model, Ferro Fanton and Henderson models gave low RMSE\% and $\mathrm{P} \%$ values and the good regression coefficients. Moreover, Halsey, Oswin and the modified Oswin equations (Table 4) gave a satisfactory prediction of the adsorption equilibrium moisture content of freeze dried plain yogurt powder and freeze dried yogurt powder contain candied chestnut puree in different ratios. According to Koç et al. (2010), there is a good correlation between the experimental data and Oswin, Henderson and Halsey equations for spray dried yogurt powder studied at different temperatures within a wide water activity.

According to results of non-linear regression analysis, Smith, Iglesias-Chirife, Chung-Phost, Peleg, Modified Chung-Phost and Modified Halsey models failed to describe the sorption isotherms of freeze dried yogurt powder with candied chestnut puree, giving average values for $\mathrm{P}$ and RMSE above $10 \%$.

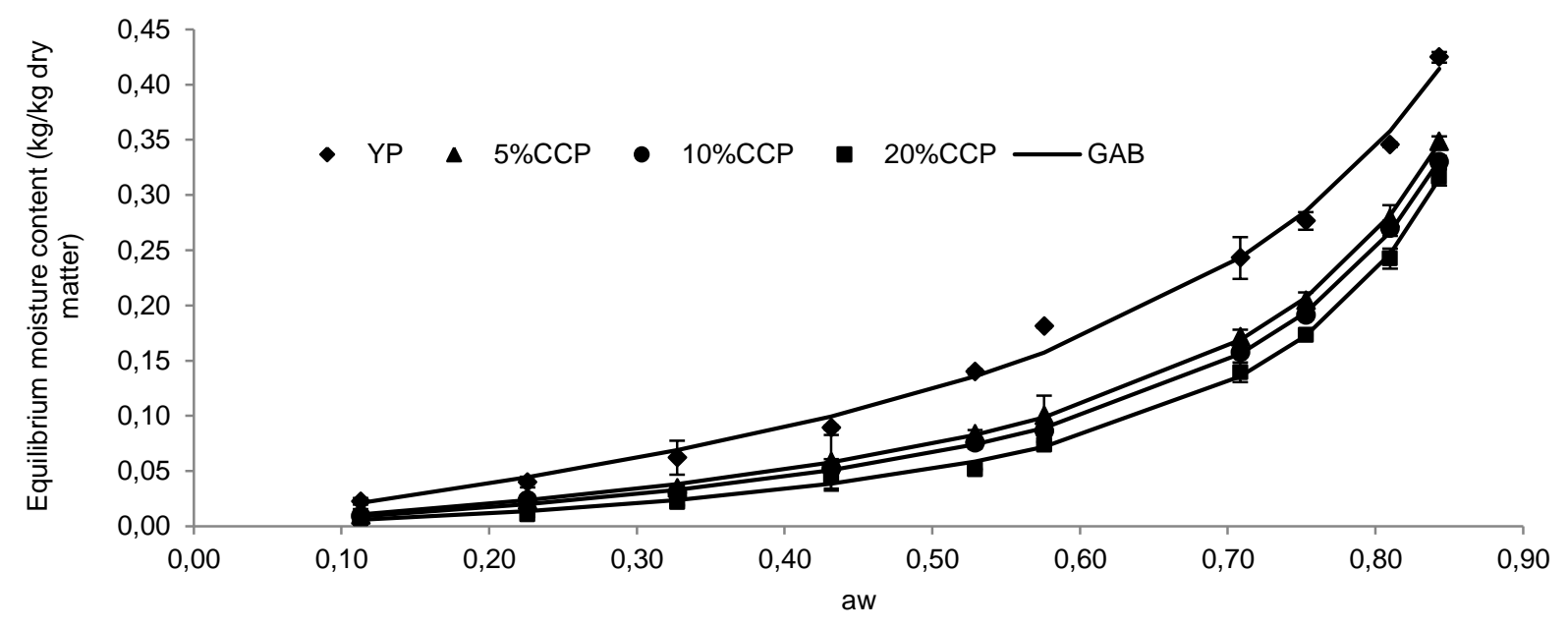

Fig. 1 Comparison of experimental and predicted from GAB model, adsorption equilibrium moisture contents of freezedried plain yogurt powder and frezee-dried yogurt powders contain 5, 10 and $20 \%$ candied chestnut puree at $25^{\circ} \mathrm{C}(\mathrm{YP}$ : Freeze dried plain yogurt powder; 5\%CCP:Freeze dried yogurt powder contain 5\% candied chestnut puree; 10\%CCP:Freeze dried yogurt powder contain 10\% candied chestnut puree; 20\%CCP:Freeze dried yogurt powder contain $20 \%$ candied chestnut puree) 
Table 4 Estimated parameters, P (\%), RMSE (\%), and $\mathrm{R}^{2}$ values of the sorption equations

\begin{tabular}{|c|c|c|c|c|c|}
\hline \multirow{2}{*}{ Model } & \multirow{2}{*}{ Parameters } & \multicolumn{4}{|c|}{ Sample } \\
\hline & & YP & $5 \% \mathrm{CCP}$ & $10 \% \mathrm{CCP}$ & $20 \% \mathrm{CCP}$ \\
\hline \multirow{6}{*}{ GAB } & $\mathrm{M}_{0}$ & 0.114 & 0.067 & 0.065 & 0.063 \\
\hline & $\mathrm{C}$ & 1.742 & 1.321 & 1.098 & 0.702 \\
\hline & $\mathrm{K}$ & 0.908 & 0.988 & 0.990 & 0.999 \\
\hline & $\mathrm{R}^{2}$ & 0.993 & 1.000 & 1.000 & 0.999 \\
\hline & $\% \mathrm{P}$ & 6.565 & 2.340 & 3.675 & 9.029 \\
\hline & $\%$ RMSE & 2.602 & 0.748 & 1.017 & 1.834 \\
\hline \multirow{5}{*}{$\mathrm{BET}^{*}$} & $\mathrm{M}_{0}$ & 0.078 & 0.077 & 0.060 & 0.058 \\
\hline & $\mathrm{c}$ & 2.382 & 0.970 & 1.246 & 0.005 \\
\hline & $\mathrm{R}^{2}$ & 0.997 & 0.994 & 0.978 & 0.986 \\
\hline & $\% \mathrm{P}$ & 3.267 & 5.138 & 7.321 & 14.687 \\
\hline & $\%$ RMSE & 0.745 & 0.845 & 1.407 & 1.713 \\
\hline \multirow{6}{*}{ MOD.OSWIN } & $\mathrm{a}$ & 16627.1 & 1233 & 7070 & 53 \\
\hline & $\mathrm{b}$ & -55.8 & -4.139 & -23.726 & -0.176 \\
\hline & $\mathrm{c}$ & 0.7 & 0.916 & 1.0 & 1.071 \\
\hline & $\mathrm{R}^{2}$ & 0.992 & 1.000 & 1.000 & 0.999 \\
\hline & $\% \mathrm{P}$ & 10.552 & 3.121 & 3.923 & 9.429 \\
\hline & $\%$ RMSE & 3.468 & 0.833 & 1.004 & 1.877 \\
\hline \multirow{6}{*}{ FERRO FANTON } & $\mathrm{a}$ & 1.772 & 1.397 & 1.298 & 1.327 \\
\hline & $\mathrm{b}$ & 0.498 & 0.298 & 0.239 & 0.271 \\
\hline & $\mathrm{r}$ & 0.443 & 0.475 & 0.509 & 0.430 \\
\hline & $\mathrm{R}^{2}$ & 0.995 & 0.999 & 0.996 & 0.993 \\
\hline & $\% \mathrm{P}$ & 3.009 & 2.449 & 4.668 & 4.973 \\
\hline & $\%$ RMSE & 2.245 & 1.623 & 3.202 & 3.636 \\
\hline \multirow{5}{*}{ HENDERSON } & $\mathrm{K}$ & 0.014 & 0.015 & 0.015 & 0.014 \\
\hline & $\mathrm{n}$ & 0.855 & 0.730 & 0.714 & 0.624 \\
\hline & $\mathrm{R}^{2}$ & 0.994 & 0.995 & 0.990 & 0.987 \\
\hline & $\% \mathrm{P}$ & 5.204 & 5.456 & 7.995 & 7.995 \\
\hline & $\%$ RMSE & 3.858 & 3.673 & 4.608 & 6.192 \\
\hline \multirow{7}{*}{ SMITH } & $\mathrm{a}$ & -0.314 & 0.782 & -0.323 & 0.778 \\
\hline & $\mathrm{b}$ & 0.001 & -0.003 & 0.001 & -0.003 \\
\hline & $\mathrm{c}$ & 32.786 & 32.774 & -32.842 & 33.019 \\
\hline & $\mathrm{d}$ & -0.109 & -0.109 & 0.111 & -0.110 \\
\hline & $\mathrm{R}^{2}$ & 0.987 & 0.965 & 0.956 & 0.940 \\
\hline & $\% \mathrm{P}$ & 15.098 & 42.689 & 51.241 & 78.762 \\
\hline & $\%$ RMSE & 4.881 & 10.177 & 11.439 & 15.178 \\
\hline \multirow{6}{*}{ IGLESIAS-CHIRIFE } & $\mathrm{k}$ & 1.344 & 1.491 & 1.514 & 1.705 \\
\hline & $\mathrm{c}$ & -1.280 & -1.648 & -1.718 & -1.980 \\
\hline & $\mathrm{R}^{2}$ & 0.936 & 0.882 & 0.865 & 0.846 \\
\hline & $\% \mathrm{P}$ & 18.126 & 24.569 & 26.351 & 28.265 \\
\hline & $\%$ RMSE & 12.670 & 17.074 & 18.218 & 19.990 \\
\hline & $\mathbf{M}_{0.5}$ & 0.125 & 0.076 & 0.069 & 0.049 \\
\hline \multirow{7}{*}{ CHUNG-PHOST } & $\mathrm{a}$ & 101.990 & 72.442 & 60.898 & 74.962 \\
\hline & $\mathrm{b}$ & -4.081 & -2.899 & -2.438 & -3.000 \\
\hline & $\mathrm{c}$ & -28.333 & -155.662 & 619.429 & 407.288 \\
\hline & $\mathrm{d}$ & 1.142 & 6.234 & 24.784 & -16.285 \\
\hline & $\mathrm{R}^{2}$ & 0.987 & 0.965 & 0.956 & 0.940 \\
\hline & $\% \mathrm{P}$ & 15.098 & 42.689 & 51.241 & 78.758 \\
\hline & $\%$ RMSE & 4.881 & 10.177 & 11.439 & 15.178 \\
\hline \multirow{5}{*}{ HALSEY } & $\mathrm{k}$ & 0.110 & 0.096 & 0.089 & 0.102 \\
\hline & $\mathrm{n}$ & 0.829 & 0.734 & 0.735 & 0.622 \\
\hline & $\mathrm{R}^{2}$ & 0.980 & 0.989 & 0.989 & 0.985 \\
\hline & $\% \mathrm{P}$ & 7.776 & 7.110 & 8.290 & 5.488 \\
\hline & $\%$ RMSE & 5.297 & 5.289 & 5.888 & 4.692 \\
\hline
\end{tabular}




\begin{tabular}{|c|c|c|c|c|c|}
\hline \multirow{5}{*}{ OSWIN } & $\mathrm{k}$ & 0.124 & 0.074 & 0.067 & 0.052 \\
\hline & $\mathrm{n}$ & 0.729 & 0.916 & 0.956 & 1.071 \\
\hline & $\mathrm{R}^{2}$ & 0.992 & 1.000 & 1.000 & 0.999 \\
\hline & $\% \mathrm{P}$ & 10.552 & 3.121 & 3.923 & 9.429 \\
\hline & $\%$ RMSE & 3.468 & 0.833 & 1.004 & 1.877 \\
\hline \multirow{7}{*}{ PELEG } & $\mathrm{k}$ & 4.482 & 3.492 & 3.309 & 2.316 \\
\hline & $\mathrm{n}$ & 22.426 & 181.351 & 199.665 & 245.099 \\
\hline & $\mathrm{b}$ & 1.743 & 3.096 & 3.335 & 3.930 \\
\hline & $\mathrm{c}$ & 0.441 & 0.547 & 0.548 & 0.579 \\
\hline & $\mathrm{R}^{2}$ & 0.997 & 0.978 & 0.979 & 0.982 \\
\hline & $\% \mathrm{P}$ & 10.056 & 29.214 & 31.418 & 34.733 \\
\hline & $\%$ RMSE & 3.351 & 6.635 & 6.914 & 6.434 \\
\hline \multirow{6}{*}{ MOD. CHUNG-PHOST } & $\mathrm{a}$ & 0.024 & 0.021 & 0.005 & 0.022 \\
\hline & $\mathrm{b}$ & 676.011 & 888.081 & 945.837 & 1001.612 \\
\hline & $\mathrm{c}$ & -24.987 & -24.987 & -24.997 & -24.985 \\
\hline & $\mathrm{R}^{2}$ & 0.965 & 0.934 & 0.921 & 0.900 \\
\hline & $\% \mathrm{P}$ & 13.554 & 18.386 & 20.074 & 22.084 \\
\hline & $\%$ RMSE & 9.981 & 12.776 & 13.717 & 15.915 \\
\hline \multirow{6}{*}{ MOD. HALSEY } & $\mathrm{a}$ & 9294.387 & 13992.683 & 19538.135 & -14377.200 \\
\hline & $\mathrm{b}$ & -371.883 & -559.815 & -781.634 & 574.981 \\
\hline & $\mathrm{c}$ & 0.905 & 1.111 & 1.153 & 1.277 \\
\hline & $\mathrm{R}^{2}$ & 0.984 & 0.997 & 0.997 & 0.996 \\
\hline & $\% \mathrm{P}$ & 21.957 & 18.367 & 16.337 & 23.386 \\
\hline & $\%$ RMSE & 6.567 & 4.160 & 3.597 & 4.132 \\
\hline
\end{tabular}

$* \mathrm{a}_{\mathrm{w}}$ range is 0.11-0.5 for BET equation. First four data was used for equation; (YP: Freeze dried plain yogurt powder; 5\%CCP:Freeze dried yogurt powder contain 5\% candied chestnut puree; 10\% CCP:Freeze dried yogurt powder contain 10\% candied chestnut puree; $20 \% \mathrm{CCP}$ :Freeze dried yogurt powder contain $20 \%$ candied chestnut puree)

\section{Conclusion}

The moisture sorption isotherms for freeze dried plain yogurt powder and freeze dried yogurt powder containing 5,10 and $20 \%$ candied chestnut puree have been obtained at $25^{\circ} \mathrm{C}$. The sorption isotherms of freeze dried yogurt powders were typical type II sigmoidal curves according to the BET classification. The GAB model showed best fitting to the sorption data of freeze dried yogurt powders with candied chestnut puree in the water activity range of 0.11-0.87at $25^{\circ} \mathrm{C}$. The adsorption data were also expressed by the BET equation in the range of water activity $0.1-0.5$. Ferro Fanton, Henderson, Halsey, Oswin and Modified Oswin models are acceptable for describing the adsorption isotherms for freeze dried yogurt with candied chestnut puree at $25^{\circ} \mathrm{C}$.

\section{References}

Al-Muhtaseb AH, McMinn WAM, Magee TRA. 2002 Moisture sorption isotherm characteristics of food products: a review. T. Am. Inst. Chem. Eng., 80:118-128.

Arslan N, Toğrul H. 2005. Modelling of water sorption isotherms of macaroni stored in a chamber under controlled humidity and thermodynamic approach. J. Food Eng., 69 (2):133-145.

Basu S, Shivhare US, Mujumdar AS. 2006. Models for sorption isotherms for foods: A review. Dry. Technol., 24:917-930.

Berlin E, Anderson BA, Pallansch MJ. 1968. Water vapor sorption properties of various dried milks and wheys. J. Dairy Sci., 51:1339-1344.

Brunauer S, Emmett PH, Teller E. 1938. Adsorption of gases in multimolecular layer. J. Am. Chem. Soc., 60:309-319.

Chenlo F, Moreira R, Fernandez-Herrero C, Vázquez G. 2006. Mass transfer during osmotic dehydration of chestnut using sodium chloride solutions. J. Food Eng., 73(2):164-173.
Chirife J, Buera MP. 1994. Water activity, glass transition and microbial stability in concentrated semi moist food systems. J. Food Sci., 59:921-927.

Chung DS, Pfost HB. 1967. Adsorption and desorption of water vapor by cereal grains and their products. Part I. Heat and free energy changes of adsorption and desorption, Transaction of the ASEA, 10:549-551.

Demarchi SM, Ruiz NAQ, De Michelis A, Giner SA. 2013. Sorption characteristics of rosehip, apple and tomato pulp formulations as determined by gravimetric and hygrometric methods, LWT-Food Sci Techol., 52(1):21-26.

Ergun K, Tiryaki-Gunduz G, Sakin-Yilmazer M, Dirim S, KaymakErtekin F. 2013. Freeze drying of yogurt with candied chestnut puree: survival of lactic acid bacteria and determination of physical properties. Ital. J. Food Sci., 25(4):470-475.

Ferro Fontan C, Chirife J, Sancho E, Iglesias HA. 1982. Analysis of a Model for Water Sorption Phenomena in Foods. J. Food Sci.. 47:1590-1594.

Foster KD, Bronlund JN Peterson AHJ. 2004. The prediction of moisture sorption isotherms of dairy powders. Int. Dairy J., 15: 411-418.

Greenspan L. 1977. Humidity fixed points of binary saturated aqueous solutions. J. Res. Nat. Bur. Stand., 81:89-112.

Halsey G. 1948. Physical adsorption on non-uniform surfaces. Journal of Chemistry and Physics., 16,931-937.

Henderson SM. 1952. A basic concept of equilibrium moisture. Agr. Eng., 33:29-32.

Iglesias HA, Chirife J. 1978. An empirical equation for fitting water sorption isotherms of fruits and related products. Can. I. Food Sc. Tech. J., 11:12-15.

Iglesias HA, Chirife J. 1982. Water sorption parameters for food and food components. In Handbook of Food Isotherms. New York: Academic Press

Jaya S. 2009. Microstructure Analysis of Dried Yogurt: Effect of Different Drying Methods. Int. J. Food Prop., 12(3):469-481.

Kamruzzaman M, Islam MN, Rahman MM. 2002. Shelf life of different types of curd at room and refrigeration temperature. Pakistan Journal of Nutrition, 1:234-237. 
Kaymak-Ertekin F, Gedik A. 2004. Sorption isotherm and isosteric heat of sorption for grapes, apricots, apples and potatoes. J. Food Eng., 37:429-438.

Kaymak-Ertekin F, Sultanoğlu M. 2001. Moisture sorption isotherm charactersitics of peppers. J. Food Eng., 47:225-231.

Kim SS, Bhowmik SR. 1994. Moisture sorption isoterms of concentrated yogurt and microwave vacuum dried yogurt powder. J. Food Eng., 21:157-175.

Koç B, Sakin-Yilmazer M, Balkır P, Kaymak-Ertekin F. 2010 Spray drying of yogurt: Optimization of process conditions for improving viability and other quality attributes. Dry. Technol., 28:495-507.

Kumar P, Mishra HN. 2002. Effect of stabilizers on mango soymilk fortified yogurt. Proceedings of International Conference on Innovations in Food Processing Technology and Engineering, pp 111-118. 11-13 December. Bangkok: AIT.

Kumar P, Mishra HN. 2004. Yogurt powder-A review of process technology, storage and utilization. Food Bioprod Process., 82:133-142.

Kumar P, Mishra HN. 2006. Moisture sorption characteristics of mango-soy fortified yogurt powder. Int. J. Dairy Tech., 59:2228.

Labuza TP. 1984. Moisture Sorption: Practical Aspects of Isotherm Measurement and Use. American Association of Cereal Chemists, St. Paul, MN.

Lomauro CJ, Bakshi AS, Labuza TP. 1985. Evaluation of food moisture sorption isotherm equations, Part I. Fruit, vegetable and meat products. Lebensm-Wiss Technol., 18:111-117.

Madamba PS, Driscoll RH, Buckle KA. 1994. Predicting the sorption behaviour of garlic slices. Dry. Technol., 12:669-683.

Mishra VK, Ooraikul B, Temelli F. 1996. Physical characterization and water sorption of freeze-dried dulse Palmaria palmata powder. J. Food Process. Pres., 20:25-39.

Moreira R, Chenlo F, Chaguri L, Fernandes C (2008) Water absorption, texture, and color kinetics of air-dried chestnuts during rehydration. J. Food. Eng. 86(4):584-594

Mosquera LH, Moraga G Martínez-Navarrete N. 2012. Critical water activity and critical water content of freeze-dried strawberry powder as affected by maltodextrin and arabic gum. Food Res. Int., 47(2):201-206.

Mrad ND, Bonazzi C, Boudhrioua N, Kechaou N, Courtois F. 2012. Moisture sorption isotherms, thermodynamic properties, and glass transition of pears and apples. Dry. Technol., 30 (13):1397-1406.

Oswin CR. 1946. The kinetics of packing life. III. The isotherm, Journal of Chemical Industry., 65:419-423.

Paakkonen K, Roos YH. 1990. Effect of drying conditions on water sorption and phase transitions of freeze dried horseradish roots. J. Food Sci., 55: 206-209.
Peleg M. 1988. An Empirical Model for the Description of Moisture Sorption Curves. J. Food Sci., 53:1249-51.

Rapusas RS, Driscoll RH, Buckle KA. 1993. Moisture desorption characteristics of raw onion slices. Food Aus., 45(6):278-284.

Rockland LB, Nishi SK. 1980. Influence of water activity on food product quality and stability. Food Technol., 34:42-50.

Rockland LB, Stewart GF. 1981. Water Activity: Influence on Food Quality, New York: Academic Press.

Silva EK, Fernandes RVDB, Borges SV, Botrel DA, Queiroz F. 2014. Water adsorption in rosemary essential oil microparticles: Kinetics, thermodynamics and storage conditions. J. Food Eng., 140:39-45.

Slade L, Levine H. 1991. Beyond water activity: recent advances based on an alternative approach to the assessment of food quality and safety. Crit. Rev. Food Sci., 30 (2-3):115-360.

Sopade PA, Ajisegiri ES. 1994. Moisture sorption study on Nigerian foods: Maize and Sorghum. J. of Food Process Eng., 17:33-56.

Spiess WEL, Wolf W. 1983. The results of the COST 90 project on water acitvity. In R. Jowitt et al. (Eds.), Physical properties of Foods, (pp. 65-91.), London, Applied Science Publishers.

Staudt PB, Tessaro IC, Marczak LDF, Soares RdeP, Cardozo NSM. 2013. A new method for predicting sorption isotherms at different temperatures: Extension to the GAB model. J. Food Eng., 118(3):247-255.

Stencl J. 2004. Modelling the water sorption isotherms of yogurt powder spray. Math Comput. Simulat., 65:157-164.

Tsami E, Marinos-Kouris D, Maroulis ZB. 1990. Water sorption isotherms of raisins, currants, figs, prunes and apricots. J. Food Sci., 55:1594-1597.

Van den Berg C. 1985. Development of B.E.T. like models for sorption of water of foods; theory and relevance. In D. Simatos and J. L. Multon (Eds.), Properties of Water in Foods, (pp. 119) Dordrecht, Martinus Nijhoft Publishers

Varghese K, Ramachandrannair SV, Mishra HN. 2009. Moisture sorption characteristics of curd (Indian yogurt) powder. Int. J. Dairy Tech., 62(1):85-92.

Vázquez G, Chenlo F, Moreira R. 2001. Modelling of desorption isotherms of chestnut: Influence of temperature and evaluation of isosteric heats. Dry. Technol., 19(6):1189-1199.

Vilades SL, Malec LF, Gerchenson LN Alzamora SM. 1995. Water sorption characteristics of sugar impregnated strawberries. Dry. Technol., 13:1993-2010.

Wang N, Brennan JG. 1991. Moisture sorption isotherm characteristics of potatoes at four temperatures. J. Food Eng., 14:269-282.

Wolf W, Speiss WEL, Jung G. 1985. Standardization of Isotherm Measurement, pp. 661-679, in D. Simatos \& J.L. Multon (Eds.) Properties of Water in Foods, Marins Ni 